\title{
THE IMPORTANCE OF SHADOW BANKING SECTOR ENTITIES FOR POPULATION AFFECTED BY CREDIT EXCLUSION
}

Key words: shadow banking, financial exclusion, social lending. J E L Classification: D30, G23, L14, 017.

\begin{abstract}
The entities included in shadow banking sector, referred to as alternative financial services providers, render services similar to banking ones. They are neither covered by banking law regulations nor subject to state supervision, but create a parallel banking system. The institutions attract clients originating mainly from the group of financially excluded individuals, rejected by banks as the result of their insufficient creditworthiness, or negative history of previously contracted debts. The objective of hereby paper is to identify advantages and threats resulting from activities performed by entities functioning in the shadow banking sector with reference to people suffering credit exclusion. Among advantages the following have to be listed: the provision of financing sources for consumer expenditure which facilitates household finances management; entrepreneurship promotion among the unemployed or the deprived of an opportunity to start their own business. Among threats the following should be emphasized: the danger of getting into the spiral of debt; inability to take advantage of consumer bankruptcy procedure; the threat of advancing poverty in such households which do not manage to have proper control of personal finance owing to poor knowledge and the absence of financial skills.
\end{abstract}

Data wpłynięcia: 30.10.2013; data zaakceptowania: 31.12.2013.

* Dane kontaktowe: malgorzata.solarz@ue.wroc.pl, Katedra Finansów i Rachunkowości, Wydział Ekonomii, Zarządzania i Turystyki, Uniwersytet Ekonomiczny we Wrocławiu, ul. Nowowiejska 3, 58-500 Jelenia Góra, tel. 757538261. 


\title{
ZNACZENIE PODMIOTÓW SEKTORA SHADOW BANKING DLA OSÓB WYKLUCZONYCH KREDYTOWO
}

Słowa kluczowe: shadow banking, wykluczenie finansowe, social lending. Klasyfikacja J E L: D30, G23, L14, 017.

\begin{abstract}
Abstrakt: Podmioty sektora shadow banking, nazywane alternatywnymi pośrednikami finansowymi, świadczą usługi podobne do bankowych. Nie obowiązują ich przepisy prawa bankowego, nie podlegają pod państwowy nadzór finansowy, tworzą równoległy system bankowy. Klientami tych instytucji są z reguły osoby wykluczone, odrzucone przez banki z uwagi na niewystarczającą zdolność kredytową bądź negatywną historię spłat wcześniej zaciągniętych długów. Celem niniejszego artykułu jest zidentyfikowanie korzyści i zagrożeń związanych z działalnością podmiotów sektora shadow banking $\mathrm{w}$ aspekcie osób dotkniętych wykluczeniem kredytowym. Po stronie korzyści należy wymienić: dostarczanie źródeł finansowania wydatków konsumpcyjnych, co ułatwia zarządzanie finansami gospodarstwa domowego; promowanie przedsiębiorczości wśród bezrobotnych, pozbawionych możliwości rozpoczęcia własnej działalności gospodarczej. Natomiast po stronie zagrożeń znajdują się: niebezpieczeństwo wpadnięcia w spiralę zadłużenia; niemożność skorzystania z procedury upadłości konsumenckiej; groźba pogłębienia ubóstwa gospodarstw domowych, które nie radzą sobie z zarządzaniem finansami osobistymi z uwagi na niską wiedzę i umiejętności finansowe.
\end{abstract}

Translated by Małgorzata Solarz

\section{INTRODUCTION}

Swift development of financial market represented one of the most important transformations brought about by the globalization processes. It turned out possible owing to several processes: deregulation, the development of new information technologies, as well as the creation and implementation of more and more complex financial instruments. As the result of these processes, in the period of recent several years, the structure of financial market, covering two parallel systems, was established. One of them was represented by the traditional banking system. The parallel system including non-banking financial institutions was also created, and referred to as shadow banking or alternative financial services provision, the role of which has grown significantly over the recent decade. The most important attribute of such system was the fact that it was functioning outside both the regulations in force and the state supervision system and therefore was referred to as shadow banking. 
Both products and services offered by alternative financial services providers were mainly appreciated by households deprived of creditworthiness and offered them an opportunity to take advantage of bank credits. Individuals forced by their personal situation to take high-interest loans outside banking system frequently find themselves in a trap of indebtedness and therefore join the group of population affected by credit exclusion. In the perspective of the observed tendencies the objective of hereby paper is to identify advantages and threats resulting from activities performed by entities functioning in the shadow banking sector with reference to people suffering credit exclusion.

\section{RESEARCH METHODOLOGY}

Applied research methods are a method of descriptive and simple statistical methods that were used to analyze the data from The Global Financial Inclusion Database and the report entitled The market of loan companies in Poland.

\section{SHADOW BANKING SECTOR - THE CONCEPT AND ENTITIES}

The term 'shadow banking' was probably used for the first time by P. McCulley, the director of PIMCO investment company at a scientific conference held at the end of 2007. In accordance with this definition the shadow banking system is understood as the entire spectrum of transactions representing traditional banking services (i.e. obtaining financial means from savers and investors and borrowing these means to credit recipients), however, featuring different status. In case of these operations realization outside banking sector the possibility of avoiding banking regulations occurs, since these transactions are not controlled by supervision institutions adequate for the financial market (Iwaisako 2010,347-368).

The first research studies on shadow banking, by such authors as Pozsar (2008) and also Adrian and Shin (2009), were published a year later. The interest in this subject matter was gradually increasing and hence more research was initiated by both economists and lawyers. Among them the following should be listed: Gorton and Metrick (2010, 2012), Ordoñez (2013), Gennaioli, Shleifer, Vishny (2013), or Schwarcz (2012) and Ricks (2010).

In October 2011 the Financial Stability Board (FSB) - the institution which supports and coordinates activities performed by the largest national financial bodies at an international level - defined "shadow banking as the system of 
credit intermediation which covers units or types of activities outside the regulated banking system" (Shadow Banking 2011). It means that shadow banking sector is made up of e.g. entities involved in:

- accepting deposits (which are not guaranteed),

- transforming liquidity and transferring credit risk,

- offering securitization, securities landing and transactions warranted by repurchase (Zaleska 2012,16).

Further part of the paper discusses alternative financial institutions which have loan products in their offer. One of the criteria for classifying products is the purpose of their operations. It divides these institutions into commercial (e.g. moneylenders, pawnbrokers) and not-for-profit (e.g. credit unions, microfinance institutions) ones (Anderloni 2008).

Entities included in shadow banking sector can be divided into two groups considering legal and moral legitimacy of their operations. E.g. loans granting entities may be characterized by the fact that they follow legislation in force, i.e. enter into written loan agreements, do not conceal key information regarding debt repayment or its actual cost, do not resort to activities forbidden by law addressed at unreliable debtors. The second group covers entities to which the above qualities do not refer and lending money at high interest is a standard service. In spite of the fact that the, so called, anti-usury Act - Official Gazette of 2005 no. 157, item 1316 - prohibits lending money in Poland at an interest higher than 16\% annually, lenders include all types of fees or insurance charges in loan agreements which increase debt servicing costs to several hundreds or even thousands percent annually.

Another classification criterion - the form of financial services provision is used to distinguish two groups of entities representing shadow banking sector. The first group renders traditional services in its official agency or in client's house, while the second provides electronic services, i.e. by means of the Internet. In the latter case it refers to social lending portals (peer-to-peer lending). Loans are mutually granted by an online functioning community without bank intermediation. It is carried out either following the principle of one creditor - one debtor, or according to the pattern - a given creditor transfers the offered amount to a few different borrowers while a particular borrower, having entered the transaction, becomes the debtor of a few individuals simultaneously. The pioneer service offering intermediation in peer-to-peer lending scheme was called ZOPA, initiated in Great Britain in 2005. In a short time it gained numerous followers, also in Poland, where in 2007 Kokos.pl started functioning. 
Its owner is Blue Media Joint Stock Company. In the course of recent years many portals were set up, however, the vast majority were finalizing their activities relatively quickly, so that the number of active social lending service ranged approximately from 5 to 6 . Attention should be paid to Pozycz.pl, Sekrata.pl or Zakra.pl.

\section{PEOPLE AFFECTED BY CREDIT EXCLUSION AS CLIENTS OF ENTITIES REPRESENTING SHADOW BANKING SECTOR}

The experts from the European Commission in their document entitled Financial services provision and prevention of financial exclusion have presented the definition of financial exclusion. According to them it refers to the process which affects people who experience problems in accessing and/or using financial products and services at the mainstream market which are adequate for their needs and support them in living a normal life in a society (Anderloni 2008). Among the areas of exclusion understood in such way credit exclusion can be distinguished and referred to the inability of taking out a lawn. Additionally, it should be emphasized that the authors of the quoted study refer the problem of financial exclusion only to the formally functioning and state supervised financial institutions disregarding, at the same time, issues related to alternative financial services providers. Therefore, those individuals who are not able to obtain a bank credit, however, take advantage of products and services offered by shadow banking sector, are included in the group of population affected by credit exclusion.

People who have been excluded by banks, owing to their insufficient creditworthiness (low income households), or due to negative history of previously contracted debts repayment, represent crucial clients of the alternative loan providing institutions. State authorities, for the sake of financial system stability, and mainly as the result of financial crisis, have introduced more stringent prudential standards. Such legislation, instead of protecting client's interests, frequently and paradoxically pushes him/her into the trap of indebtedness. A person who has low income, or obtains income from an undeclared work does not represent a trustworthy partner for banks. And it is such population - financially excluded - which constitutes core clientele of alternative financial services providers. This group often covers low educated individuals, from smaller locations and affected to a greater extent by the job market problems (Białowolski 2012). 
Among clients there are also those who could take a bank credit without any problem, however, they decide to apply for a loan at alternative intermediaries. The explanation seems to be the lack of knowledge. The research conducted for Kronenberg Foundation confirms that the level of financial capability represented by Polish population is poor (Maison 2013) and decreases proportionally to respondents' aging. Pensioners, who frequently become customers of alternative financial services providers, rarely compare offers of several institutions in order to select the most favourable one. This would require paying a visit in a few banks or checking several websites and additionally, in the latter case, the problem of senior citizens digital exclusion becomes visible (only 10,6\% of Poles over 65 years of age were using the Internet in 2011 (Czapiński, Panek 2012). Many elderly persons claim that they feel much more comfortable when an agent visits them at home and in such circumstances the costs of taking out a loan become less important. And it is, indeed, the sense of security that such loan offering companies as e.g. Provident take advantage of in their activities.

In accordance with data collected by The World Bank in 148 countries the number of people, who in 2011 took out a loan, amounted to 33,8\%. The majority of respondents refer to friends and family for financial support $-22,7 \%$, next in line are loans offered by mainstream financial institutions $-9,1 \%$ and private creditors are ranked as the third $-3,4 \%$. These figures differ depending on the world region (chart 1). Additionally, following FSB estimations the size of shadow banking sector entities in 2010 presented the level of 46000 billion Euro, i.e. half of total bank assets (Shadow Banking Green Paper 2012).

Data presented in the 1 chart confirm that the highest indebtedness was characteristic for the population of Sub-Saharan Africa - 46,8\%, while the least debts were contracted by Latin America and The Caribbean inhabitants $-25,4 \%$. As far as financing sources are concerned, apart from the developed countries, loans from family or friends represent the dominating source of financial support. The broadly understood alternative offer of loan granting institutions is most popular among the adult population of South Asia - 6,4\% and the lowest interest of such services, at the level of 1,5\%, is recorded among inhabitants of Europe and Central Asia. 
Chart 1. The number of borrowers and basic sources of loans in regional cross-section (data form 2011 presented as \% of population over 15 years of age)

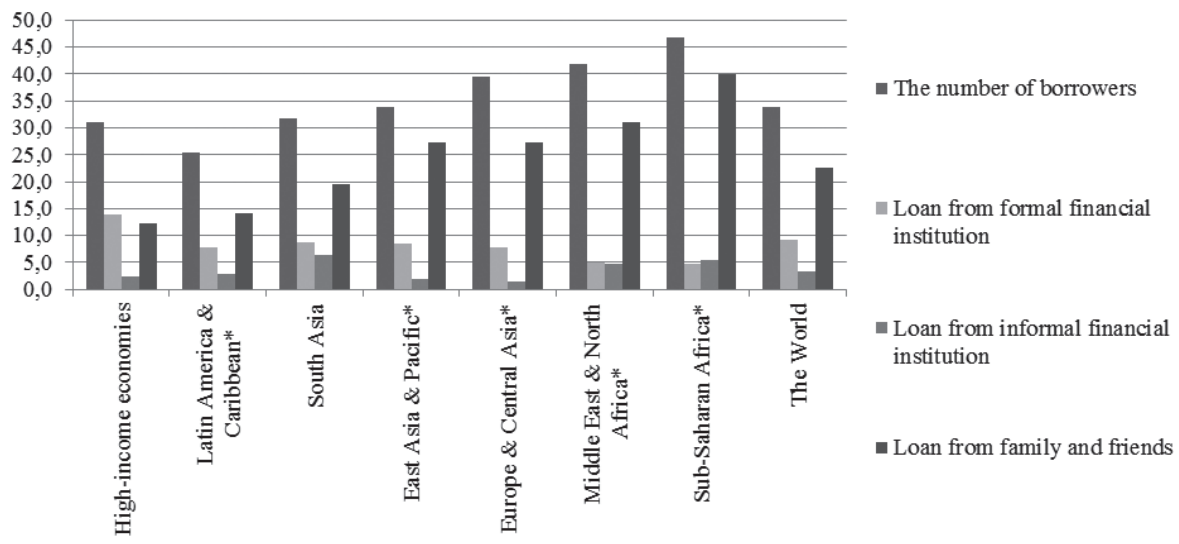

* only developing countries

S o u r c e : Author's compilation based on (The Global Financial 2013).

Polish citizens, against the global average, have slightly worse results since last year $26,4 \%$ of adult population took out loans, among which 13,5\% borrowed money from family and friends, while ten out of one hundred signed loan agreements with banks and 0,9\% took advantage of alternative financial services providers (The Global Financial 2013). On the other hand, another source reports that, in the first half of 2012, the indebtedness of Polish citizens to shadow banking sector entities amounted to 1,8 billion PLN, which constitutes the increase by $17 \%$ as compared to the previous year (Kamińska 2012,1). The number of non-banking lending institutions keeps growing dynamically. The Confederation of Financial Companies informs that at the end of 2012 the number of borrowers amounted to 1,36 $\mathrm{mln}$, whereas three years before the adequate number was 900 thous., which means an increase by 33\%. For many years the offer by the lending company - Provident has been most popular in Poland. At the end of the 3rd quarter of 2013 it recorded almost 3\% growth of clients and $4 \%$ of the value of loans granted. It is also worth emphasizing that a much less popular form of selling loans by the Internet appeared on Polish market. Such loans providers as Net Credit, Kredito24, Wonga.com, Vivus Finance, running their businesses online, have been conquering the market dynamically. E.g. the latter entity, only in the first year of running the business, served 300 thous. clients and granted loans at the total amount of PLN $250 \mathrm{mln}$. These types of 
loan companies offer the so-called micro-loans to be repaid within 30 days. In 2013 the average borrowed amount was PLN 449 in case of the first agreement and PLN 745 for clients granted another micro-loan, if the prior one was repaid in full amount and timely. Micro-loans are repaid as balloon payments or - if applied by a client - extended for the following repayment period. Quite often they do not bear interest and their total cost is the commission enlarging the amount repaid at the end of the crediting period. Average costs of debt servicing remain at the level of 19-23\% against the borrowed amount (Raport 2013, 3-5). Additionally, the number of social lending portals users is also growing dynamically, Kokos.pl informs at its website that in September 2013 they had over 225000 clients, while nine months before their number was by 7,6\% lower.

\section{AdVANTAGES RELATED TO OPERATIONS PERFORMED \\ BY SHADOW BANKING SECTOR ENTITIES FOR POPULATION AFFECTED BY CREDIT EXCLUSION}

Alternative financial services providers offer numerous advantages, especially for individuals affected by the exclusion from financial system. These entities provide financing sources for both consumer expenditure and these related to starting one's own business. The access to loan products facilitates household finance management, e.g. allows for covering temporary shortage of financial resources or protects against suffering even deeper poverty as the result of such circumstances as health problems or an injury of the primary breadwinner. For many of them even small amounts in loans allow for life quality improvement, e.g. by exchanging old household appliances into new ones, buying pharmaceuticals, financing education courses. The report entitled "The market of loan companies in Poland" presents research results referring, among others, to household indebtedness in financial institutions from the perspective of objectives behind taking out loans. As it turns out, in case of debts contracted in loan institutions functioning outside banking sector the slightly higher percentage of households take out loans for their current consumption purposes than it is observed in case of credits granted by banks $(23,2 \%$ against $16,6 \%)$. Unfortunately, as far as households outside the formal sphere of borrowing are concerned and these taking loans from private persons, the scale of indebtedness for current consumption purposes is significantly higher. In the group of households reporting financial obligations to private persons as many as $51,1 \%$ have borrowed money to purchase current consumption goods (Białowolski 2012). 
Another important advantage is the fact that they promote entrepreneurship among the unemployed, deprived of opportunities for initiating their own business based on financial means at their disposition and at the same time unable to apply for them at banks. In this area the significant role is played by microfinance institutions. Support they provide allows borrowers to enter the job market, earn money and therefore supply their households with income resulting in its members life quality improvement. What is more, microfinance opens opportunities for poor people becoming independent and in consequence relieves the financial burden of the state (social care).

Additionally, the alternative financial services providers by means of their operations in developing countries and inhabited by poor population, support personal development of potential borrowers, mainly women. Research results carried out in Asian villages, where microfinance institutions are very active, indicate that illiteracy rate among women in these areas dropped since they have their own capital, or property (e.g. land) at their disposal, they participate in undertaking decisions about their own household, they are victims of domestic violence less often (Dowla, Barua 2006).

The operations performed by alternative financial services providers steal, to an extent, clients from the leading financial institutions (the Internet micro-loans are an exception), which results in an intensified competition battle between them which can result in more favourable terms and conditions of financial products offered by the latter entities and the recognition of financial exclusion problem.

\section{THREATS RELATED TO OPERATIONS PERFORMED BY SHADOW BANKING SECTOR ENTITIES FOR POPULATION AFFECTED BY CREDIT EXCLUSION}

The advantage of an opportunity to take out a loan from many alternative financial intermediaries may, in case of financially excluded individuals, simultaneously result in over indebtedness (such situation means no possibility to meet deadlines of all contracted debts). If it is the case, the instalments for one entity are paid by means of the loan taken out at another one and therefore the loop of indebtedness keeps escalating. Data included in P. Białowolski's report (2012) confirm that every seventh Polish household indebted in the non-banking loan sector uses the obtained means to pay back previous commitments. As the result the problem of financial exclusion may become even stronger and un- 
fortunately the number of over indebted population in Poland keeps growing steadily presenting the level of 300000 people.

The problem of excessive debt occurring at the microloans market was noticed by scientists from The University of Zurich and their conclusions, to a large extent, also confirm the consequences of activities performed by the remaining alternative loan granting institutions. Unrestrained access to financing sources, especially in case of individuals who cannot manage their personal finance satisfactorily, instead of their household economic situation improvement, can result in deeper poverty while the building up stress may even end up in a nervous break down or a suicide of an affected individual (Kappel i in. 2010). In 2010 there were reported cases of suicides among women who borrowed money from SKA Microfinance in India and had problems with their repayment. This institution was established in 1997 as a non-profit organization and in the initial period of its functioning it was cooperating with Grameen Bank founded by M. Yunus, awarded with the Nobel Peace Prize, and implemented his noble ideas. The success of microloans attracted investors, venture capital funds of commercial nature. Unfortunately the new owners have changed radically both values and methods of functioning and focused on profit maximizing not necessarily perceived from the perspective of social benefits (Janikowska 2011, 75-83).

At this point it is worth mentioning that the debt spiral deprives over-indebted persons from taking advantage of consumer bankruptcy procedure (see "Official Gazette" of 2008 no. 234, item 1572). The mentioned above legislation allows, once in ten years, to get rid of debt through declaring bankruptcy by an insolvent natural person, who owing to random events beyond any of his/her influence, became insolvent.

The disadvantage of social lending, as the tool for fighting social exclusion, is manifested in the fact that it does not work for poor families who do not have computer or the Internet access. The absence of adequate equipment is frequently accompanied by the inability of using it and functioning in the virtual world and therefore entering into social lending type of agreements (Solarz 2011, 179-192).

\section{CONCLUSIONS}

Both Europe and Poland experience the results of global financial crisis manifested by more prudent credit decisions undertaken by banks. These institutions, having considered higher risk, but also new, more stringent prudential 
measures, try to counteract the development of over-indebtedness among their clients and upgrade the level of bank sector security. On the other hand, there are quite noticeable side effects. More restrictive criteria for credit granting by banks, accompanied by detailed verification of the potential clients' current records are manifested by the growing amount of financially excluded population. Such individuals are not capable of obtaining positive credit decisions since they do not have adequate income and/or assets, and also their credit record includes information perceived by banks as the threat to loan repayment. To an extent, the response to such uncovered demand is visible in an increased activity of shadow banking sector entities, including mainly loan offering companies.

Alternative financial services providers have already become the firm part of financial market structure by providing their services mainly for this part of society which is outside the interest of banks for either commercial or formal reasons. The offer of micro-loans to be repaid within a month is complementary rather than substitutive with regard to bank offer. It is addressed to the individuals suffering credit exclusion due to the fact that they perform seasonal or casual work or represent shadow economy, however, those whose income suggests that they are capable of repaying their debt timely. The problem to be discussed is the level of how detailed the legal regulations covering the services offered by lending companies should be, so that it ultimately serves the financial market and therefore to the benefit of economy and most of all the citizens.

Based on the primary advantages and threats experienced by the population affected by credit exclusion, presented in the hereby paper, which refer to the functioning of alternative financial intermediaries it may be concluded that it is the advantages which constitute the majority. The threats, however, have to be considered regarding by whom and what kind of activities should be undertaken in order to reduce their scale.

E.g. low financial awareness of Polish society, manifested by problems in distinguishing banks from lending institutions or the inability to calculate the total cost of the loan granted, can be eliminated by all sorts of initiatives undertaken by the state or by the financial services providers (see Solarz 2013, 156-166)). This type of operations, which are supposed to prevent the socially undesirable phenomenon of financial exclusion and restore the excluded population back to the financial system, are referred to as financial inclusion. In accordance with the theses presented in the document issued by The World Bank they should follow the idea of responsible finance also supported by: the state, both mainstream and alternative financial services providers, as well as 
consumers themselves (Advancing Responsible Finance 2011). All these entities, adequately to their capacity should be active in such areas as: customer protection, responsible service providers and the development of client financial capacity.

\section{REFERENCES}

Adrian T., Shin H. S. (2009), The Shadow Banking System: Implications for Financial Regulation, Federal Reserve Bank of New York Staff Report no. 382, http://dx.doi.org/10.2139\%2Fssrn.1441324.

Advancing Responsible Finance for Greater Development Impact (2011), Responsible Finance Forum, Available on the website http://www.ifc.org/ (access: 02.10.2013).

Anderloni L. (2008), Financial services provision and prevention of financial exclusion, European Commission, http://ec.europa.eu/social/main.jsp?langId=en\&catId=22 (27.09.2013).

Białowolski P. (2012), Rynek firm pożyczkowych w Polsce. Konferencja Przedsiębiorstw Finansowych w Polsce, Warszawa, Available on the website http://alebank.pl/ (access: 15.10 .2013$)$.

Czapiński J., Panek T. (2012), Diagnoza społeczna 2011. Warunki i jakość życia Polaków, Ministerstwo Pracy i Polityki Społecznej. Warszawa.

Dowla A., Barua D. (2006), The Poor Always Pay Back. The Grameen II Story, Kumarian Press, Bloomfield.

Gennaioli N., Shleifer A., Vishny R. (2013), A Model of Shadow Banking , ,Journal of Finance", vol. 68, Issue 4, http://dx.doi.org/10.1111\%2Fjofi.12031.

Gorton G., Metrick A. (2010), Regulating the Shadow Banking System, "Brookings Paper on Economic Activity”, vol. 41, Issue 2, http://dx.doi.org/10.1353\%2Feca.2010.0016.

Gorton G., Metrick A. (2012), Securitized Banking and the Run on Repo, „Journal of Financial Economics", vol. 104, Issue 3, http://dx.doi.org/10.1016\%2Fj.jfineco.2011.03.016.

Iwaisako T. (2010), Global Financial Crisis, Hedge Funds and the Shadow Banking System, "Public Policy Review", vol. 6, no. 3.

Janikowska E. (2011), W jaki sposób mikrofinansowanie pomaga w walce z ubóstwem. Studium przypadku Grameen Bank, „Ekonomia Społeczna”, no. 2.

Kamińska A. (2012), W matni para banków, „Rzeczpospolita”, nr 9311.

Kappel V., Krauss A., Lontzek L. (2010), Over-indebtedness and Microfinance. Constructing an Early Warning Index. Center for Microfinance - University of Zurich, http:// www.accion.org/Document.Doc?id=899 (access: 03.10.2013).

Maison D. (2013), Polak $w$ świecie finansów, WN PWN, Warszawa.

Ordoñez G. L. (2013), Sustainable Shadow Banking, "National Bureau of Economic Research Working Paper", no. 19022.

Pozsar Z. (2008), The Rise and Fall of the Shadow Banking System, http://www.economy. com/sbs (27.12.2013). 
Raport - Mikropożyczki w Polsce (2013), Związek Firm Pożyczkowych, http://zfp.org. pl/ (access: 28.12.2013).

Rick M. (2010), Shadow Banking and Financial Regulation, "Columbia Law and Economics Working Paper”, no. 370, http://dx.doi.org/10.2139\%2Fssrn.1571290.

Schwarcz S. (2012), Regulating Shadow Banking, „Review of Banking and Financial Law", vol. 31, no. 1.

Shadow Banking Green Paper (2012), European Commission, http://ec.europa.eu/internal_market/bank/docs/shadow/green-paper_en.pdf (access: 17.09.2013).

Shadow Banking: Strengthening Oversight and Regulation (2011), The Financial Stability Board. http://www.financialstabilityboard.org/publications/r_111027a.pdf (access: 27.12.2013), http://dx.doi.org/10.2139\%2Fssrn.2182601.

Solarz M. (2011), The role of social lending in financial inclusion, [in:] Financial sciences, E. Bogacka-Kisiel (ed.), "Research Papers of Wroclaw University of Economics", no. 184.

Solarz M. (2013), Financial capability development as the responsible finance instrument counteracting financial exclusion, [in:] Finance and Accountancy for Sustainable Development - Sustainable Finance, G. Borys, M. Solarz (eds.), "Research Papers of Wroclaw University of Economics", no. 302.

The Global Financial Inclusion Database (2013), The World Bank, http://databank.worldbank.org (30.09.2013).

Zaleska M. (2012), Szara bankowość, „Gazeta Bankowa”, nr 9. 
